\title{
Due Diligence in Mergers and Acquisitions in Emerging Markets: Evaluated Risk Factors From the Academic and Practical View
}

\begin{abstract}
Alen Sacek
University of Latvia, Riga, Latvia

The obviously ever increasing number of corporate acquisitions in recent decades has improved the general knowledge and awareness of due diligence for both the industry and research. In the current challenging business environment, acquisitions face a higher degree of risk profiles, especially cross-border acquisitions in the emerging markets. Conducting a thorough due diligence investigation in the context of an acquisition is more important now than ever. In a broad analysis, this paper researches the key risk factors in the acquisition process and their assessment within a due diligence audit in the acquisition phase. The task of this paper is to match the academic and practical view in order to give a more complete understanding of risk factors to be covered in due diligence audit. The starting point is the research of academic findings which basically concentrate on common approaches considering financial, legal, commercial, and some other issues in domestic acquisitions and in developed countries. In contrast, this paper considers risk factors in cross-border and emerging markets transactions. In addition, a number of business consultants publish studies based on surveys on this topic which reflect typical risk factors based on experience of their customers being involved in cross-border acquisitions. Their risk assessment consists of specific regulatory, political, and other factors, which may lead to commercial and reputational impediments in cross-border acquisitions. The outcome of the comparison is a comprehended list of evaluated risk factors, whereby the academic findings are complemented and supported by the practical experience in the business consultant's studies. Moreover, the practical approach points to the fact that due diligence scope needs to be suited to the dynamics of the markets. The comparison and the comprehended list of evaluated risk factors call for a more integrated system of due diligence and show herein the research deficit. Hence, the novelty is the compendium of evaluated risk factors which should be assessed in the pre-acquisition phase. The originality of the paper is given by a unique analysis of academic work about acquisition due diligence literature and consultant studies from anonymized practical experience based on insider information.

Keywords: due diligence, emerging markets, mergers and acquisitions (M\&A), risk, investment
\end{abstract}

\section{Introduction}

The topic of mergers and acquisitions (M\&A) has been increasingly investigated in the literature in the last two decades (Hitt, King, Krishnan, Makri, Schijven, Shimizu, \& Zhu, 2009) in response to the rise in M\&A activities as well as the increasing complexity of such transactions themselves (Gaughan, 2011). M\&As, in the

Alen Sacek, Ph.D. candidate, University of Latvia. Email: alen.sacek@gmail.com. 
broad sense, may imply a number of different transactions ranging from the purchase and sales of undertakings, concentration between undertakings, alliances, cooperation, and joint ventures to the formation of companies (Wirtz, 2012, p. 12). Schuler and Jackson (2001) argued that using a broad definition of M\&A can lead to confusion and misunderstanding as it entails everything from pure mergers to strategic alliance. In this paper, the definition of M\&A will be used in a narrower sense, as acquisition, as the purchase of shares or assets on another company to achieve full managerial and operational influence. Acquiring a company abroad can be motivated by the wish of entering foreign market and establish a strong position very quickly. It enables the acquirer to build on complementary knowledge and differing market prospective of the target. In that manner, it enables the realization of synergetic potentials (Gole \& Hilger, 2009, p. 42). However, acquiring a company is risky, especially because relevant information of a target's business is beyond the reach of the acquirer and he/she needs to rely on or make assumptions about the state of the business (Very \& Schweiger, 2001, p. 15). Such information asymmetry occurs when the acquirer does not get reliable information to carry out a thorough evaluation and determine the fair acquisition price. In line with the literature, the term information risk is used to describe the uncertainty surrounding information relevant to the acquirers' valuations and expectations for future economic development (Schweiger \& Very, 2003). The main challenge for the acquirer is to obtain adequate information about the target company's business. Even if the acquirer gets information in the acquisition process, there will be information buried within the target firm's bookkeeping and records, and thus difficult to find and consider in the evaluation efforts. The higher the quality of information, the better the acquirer can make qualified decisions about the economic benefits of a potential acquisition. In cross-border context, the situation is more risky, since there is even higher information asymmetry including characteristics from different countries (Firstbrook, 2008, p. 2). In M\&A transactions, due diligence serves to overcome the information asymmetry, and thus, it is defined as an audit of potential investment confirming material circumstances related to the acquisition. Due diligence comprises detailed investigation and risk assessment in a wide area of the targets specifications, either quantifiable or non-quantifiable (Angwin, 2001, p. 33; Hopkins, 1999, p. 233; Knecht \& Calenbuhr, 2007, p. 425). Due diligence is used to describe the process of acquiring objective and reliable information on acquisition target prior to the specific event. From the legal perspective, due diligence is described as "due care" and used essentially to prevent damages and/or possible harm to either party involved in transaction or business decision (Angwin, 2001, p. 33). The result of due diligence is used to provide an acquirer with enough basic information about a target to pave the way for an informed decision about whether to pursue the acquisition aims and give indications about the price and other negotiation terms. The final purpose is to give confidence of fully understanding and evaluating risks associated with the acquisition (Angwin, 2001, p. 37).

From the theoretical point of view, due diligence process mostly conforms with the perspective of organizational learning theory (Barkema \& Schijven, 2008; Shimizu, Hitt, Vaidyanath, \& Pisano, 2004), more precisely the exploratory learning (March, 1991). According to that perspective, the company learns with each acquisition and can transfer this learning effect to the subsequent acquisitions. With the repetition, acquirers gain experience and confidence as their knowledge regarding routines improves. The challenge in the acquisition process is that the acquisition process is far more complex than the operating business, such as manufacturing, pricing, distribution, etc.. Usually, the acquirer audits beyond the provided annual report data and engages audit experts in order to do further investigation steps and validate main assumptions and receive a 
clear risk profile of the target firm. The most frequently examined areas in the due diligence are the financial, legal (corporate law), and management and personnel quality and capabilities (Harvey \& Lusch, 1995; Angwin, 2001; Gomes, Angwin, Weber, \& Tarba, 2013). According to Cullinan, Le Roux, and Weddigen (2004), due diligence verifies the target's financial statements rather than evaluating the strategic logic and other sub-factors important for realizing acquisition value. Other common and more general risks relate to the existence and valuation of the assets and liabilities in the financial statement and litigation and claims against the target company.

Considering the thorough evaluation, due diligence can influence the final success or failure of cross-border acquisition and substantiate possible legal claims. Hence, the scope of due diligence should cover all material aspects of the acquisition target's operation, consisting of intense document review and analysis, questions and answers session with management, and often an evaluation of physical plant and operations (Gole \& Hilger, 2009, p. 89). The scope of due diligence has broadened in the past years as the business complexity and globalization tendencies have increased (McDonald, Coulthard, \& De Lange, 2005, p. 4).

\section{The Traditional Approach of Due Diligence}

In general, the traditional "due diligence" approach considers legal, financial, and commercial issues and is carried out by legal and accounting advisors (Belian, 2009; Harvey \& Lusch, 1995). There is an interconnecting idea between these three issues, considering the typical areas such as property rights, ownership and structure, etc. as legal issues. On the other side, the financial issues consider cash and debt servicing capacity, assets evaluation, overall profitability, and management information systems. In the commercial area, the focus lies on the strategic and marketing issues, customer management and orientation, and operations and technologies.

Before the new century, the traditional due diligence process has been primarily focused on tangible assets or documents relative to the operations of the company resulting in a "mechanical verification" of legal, accounting, and tax matters (Harvey \& Lusch, 1995). These authors divided this approach into intangible (i.e., quality of leadership, personal retention, etc.) and tangible assets (i.e., market share, related parties, etc.). Berens, Brauner, and Strauch (2011) theoretically considered further topics than the traditional approach, but combining them with financial and legal outcome without considering the critical areas which often have led to failure of the acquisitions. There seems to be a pattern emerging from both research and experience that intangible issues such as culture and change are critical to success. Some research even identifies "irrational" influences on post-merger integration. Hence, the predominant focus of due diligence remains financial and legal although the track record of M\&A deals points to shortcomings in the traditional due diligence approach (McGrady, 2005). The academic research scope comprises further of the secondary consideration of intangible assets gained from survey of members of due diligence practitioners considering audit of macro-environment, production, management, marketing, and information systems. In recent years, the operational complexity in companies has increased due to internationalization substantially. The companies implemented integrated supply chain management systems, logistics operations which must work real-time and across the borders and use extensive subcontracting and different manufacturing partners (Knecht \& Calenbuhr, 2007). These trends have also found their place in the due diligence approach. The newer scientific work, i.e., Fustec and Faroult (2011), Morrison, Kinley, and Ficery (2008), McGrady (2005), etc., investigated operational issues, i.e., supply 
chain management, sub-supplier network and assessment of employees and benefits, environmental issues, and intellectual property. In line with that, Firstbrook (2007) emphasized that the cross-border M\&As include greatest risks within cultural, regulatory, or competitive environment spheres, but concrete scientific research concentrated on due diligence proceedings on these issues, with exception of the cultural aspects, is still rare. The nature of the local environment and its nationality (for example, government policies or strong unions) may have a bearing on the ability of acquirers to implement practices during post-merger integration, such as changes in salary and benefits, recruiting, turnover, and labor relations. Not considering such issues may imply higher transaction cost and prolonged post-acquisition integration period. This issue coincides with regulatory changes in countries with a strong legal and institutional environment, which may make access to markets for firms from countries with weak legal and institutional environments more difficult (Feito-Ruiz \& Menéndez-Requejo, 2011).

The academic literature review consisted of computerized and manual queries of published research reports. The databases used were Proquest, Science Direct, Scopus, and Elsevier. The keywords used were due diligence, merger, acquisition, and risk factor. Given that literature sources were limited, the review includes qualitative and quantitative studies. Further research consisted of screening of the bibliographies, textbooks, and conference working papers with internet search machines. A total of more than 40 empirical studies, relevant to due diligence audit in M\&A, were found and considered in this paper. Conforming to their theoretical classification the analysis, the evaluated risk factors were consolidated into four different constructs:

(1) Choice of the strategic partner;

(2) Business capabilities and knowledge management;

(3) Financial factors and acquisition premium;

(4) Macro-factors and business environment.

\section{Practical Point of View}

In general, the business consulting studies argue in line with the theoretical sources that potential rewards from acquiring in emerging markets are undeniable, but the risk profile of cross-border acquisitions is rather higher than in domestic transactions (Accenture, 2008). In order to faster improve the information asymmetry through detailed risk assessment, acquirers engage business consultants specialized on the acquisition topics. Business consultants build on a regular experience basis for best practice solutions using the experience and feedbacks gained in projects with their customers (Paul, 2009). In order to supplement academic research, this research paper includes 16 market reports based on surveys that are based on experience with multinational companies in cross-border acquisitions. The selection was according to the relevance concerning risk factors in the cross-border M\&A. The surveys are focused on large, transnational transactions considering the view of top management (senior management, CEO, and CFOs) in the acquiring companies regarding the success and failure of the acquisition. The questions answered consider ratio of the acquisition, of which areas the pre-acquisition analysis consisted, expected, and achieved synergies, and about problems occurred in the post-integration phase. Moreover, how the acquisition performed relative to plans and expectations. Although the business consulting studies are insightful, they have the weakness to concentrate on one detail or of not describing in a detailed manner. The analytical results tend to be presented cursory, perhaps to save the confidentiality and proprietary information. The majority of consulting studies use the interview technique to look for factors which are mainly simplified and apply for a large number of M\&As. Further weakness is the 
lack of classification of the M\&A type. The studies analyzed mostly consider acquisitions undertaken to increase size and expand geographically or to expand own product lines in the same or related industries. These transactions have readily understandable motivations and appear more likely to succeed than those intending to move firms into completely new product areas or to expand the use of new, speculative ventures.

Kroll Advisory (2013) interviewed 50 senior managers of acquiring companies with acquisition experience in conducting due diligence on targets in emerging markets. They concluded that such due diligence requires a different approach than domestic due diligence adapting the professional approach of acquisition advisers with experience in emerging and frontier markets. In such high risk acquisitions, an acquirer opts to increase the traditional approach with concentrating on legal and tax issues. In the focus stands the inter-play between commercial and reputational issues and their implications on the M\&As in emerging markets. This is especially the case in jurisdictions with strong government involvement (e.g., its role as a regulator, an undisclosed beneficial owner in the target company, a client or a supplier, a provider of infrastructure, or a competitor). Compared to the traditional view of conducting due diligence, the survey from the M\&A practitioners points to the fact that the due diligence approach needs to be suited to the dynamics of the markets summarized as follows:

(1) Overlap between public and private sectors requires combined commercial and reputational due diligence in order to uncover potential implications of the interconnections;

(2) Questionable information quality needs to be supplemented with "on-the-ground” research;

(3) Ambiguous regulatory environment or lack of a legal framework requires plan scenarios for unforeseen events.

Deloitte's (2012) survey researched the managing compliance and integrity-related risks in acquisitions in emerging markets. The main concern for many companies is compliance and integrity-related risks in emerging markets which have had increased in the past years. The survey participants reported the need to more thoroughly analyze this relatively new risk category in order to gain knowledge of the political and regulatory environment, as well as its impact on to operation's and financial issues. A special topic is related with corruption, bribery and fraud, changeable regulatory situation as well as the implications of interaction with state-owned or state-controlled entities. This implicates further investigation questions, which are mainly subsumed under legal risk:

(1) Impact of the regulatory changes on commercial success of the business;

(2) Level of government interference or influence on the business;

(3) Steering board and their political career or exposure;

(4) Appetite for bribery in this region/sector and the compliance issues with prevailing legislation and the acquirers' reputation.

There are also other research fields, i.e., Clifford Chance (2012) researched currency fluctuations and foreign exchange risk is in the minority of the research, as those risks are handled by use of common hedging instruments. This implies more thorough investigation needs than those found in the traditional view and these uncertainties demand a thorough approach to scenario planning, i.e., for currency and asset price volatility and the acquisition needs to be stress-tested, i.e., changes in political leadership, withdrawal of government subsidies.

The single issues of each construct can be summarized in Table 1 . 
Table 1

Summary of Evaluated Risk Factors Relevant for Due Diligence Audit in the M\&A Process

\begin{tabular}{|c|c|c|}
\hline Evaluated risk factor & Selected research source & \\
\hline Choice of the strategic partner & Academic research & Business consulting \\
\hline $\begin{array}{l}\text { Strategic fit } \\
\text { Organizational fit: Operating environment } \\
\text { (e.g., IT compatibility) }\end{array}$ & $\begin{array}{l}\text { Gomes et al. (2013, p. 13); Fustec and } \\
\text { Faroult (2011, p. 496); Cullinan et al. } \\
\text { (2004); Firstbrook (2007, p. 53); } \\
\text { McGrady (2005); Gleich, Kierans, and } \\
\text { Hasselbach (2010, p. 6); Epstein (2005, } \\
\text { p. 40); Perry and Herd (2004, p. 16); } \\
\text { McDonald et al. (2005, p. 3); Angwin } \\
\text { (2001, p. 35); Child, Faulkner, and } \\
\text { Pitkethly (2001); Adolph, Gillies, and } \\
\text { Krings (2006); Zademach and } \\
\text { Rodríguez-Pose (2009, p. 771); Lee and } \\
\text { Pennings (1996, p. 31); Morrison et al. } \\
\text { (2008, p. 26) }\end{array}$ & $\begin{array}{l}\text { BCG Consulting (2012); Accenture } \\
\text { (2008); Mercer Consulting (2008); GE } \\
\text { Capital (2012); Roland Berger (2011); } \\
\text { Grant Thornton (2004); McKinsey (2010) }\end{array}$ \\
\hline Cultural fit & $\begin{array}{l}\text { Hitt et al. (2009); Fustec and Faroult } \\
\text { (2011, p. 496); Firstbrook (2008, p. 2); } \\
\text { McGrady (2005, p. 22); Shimizu et al. } \\
\text { (2004, p. 325); Very and Schweiger } \\
\text { (2001, p. 20); Marks, Mirvis, and } \\
\text { Brajkovich (2001, p. 83); Schuler and } \\
\text { Jackson (2001) }\end{array}$ & $\begin{array}{l}\text { Deloitte (2009); Baker \& McKenzie } \\
\text { (2013); Mercer Consulting (2008); } \\
\text { McKinsey (2010) }\end{array}$ \\
\hline Market position & $\begin{array}{l}\text { Haspeslagh and Jemison (1991); Harvey } \\
\text { and Lusch (1995, p. 14); Perry and Herd } \\
\text { (2004, p. 16); Bertrand and Betschinger } \\
\text { (2012, p. 417); Cullinan et al. (2004); } \\
\text { King, Dalton, Daily, and Covin (2004, } \\
\text { p. 190); Very and Schweiger (2001, p. 25) }\end{array}$ & $\begin{array}{l}\text { McKinsey (2010); GE Capital (2012); } \\
\text { Mercer Consulting (2008) }\end{array}$ \\
\hline \multicolumn{3}{|l|}{$\begin{array}{l}\text { Business capabilities and knowledge } \\
\text { management }\end{array}$} \\
\hline Business capabilities & $\begin{array}{l}\text { Haspeslagh and Jemison (1991); Morisson } \\
\text { et al. (2008, p. 27); Ahammad and } \\
\text { Glaister (2013); Bertrand and Betschinger } \\
\text { (2012, p. 417) }\end{array}$ & $\begin{array}{l}\text { BCG Consulting (2012); GE Capital } \\
\text { (2012); Roland Berger (2011) }\end{array}$ \\
\hline $\begin{array}{l}\text { Technological competence (R\&D, } \\
\text { intellectual property) }\end{array}$ & $\begin{array}{l}\text { Hitt et al. (2009); Bertrand and } \\
\text { Betschinger (2012, p. 418); Epstein (2005, } \\
\text { p. 40); McGrady (2005); Rossi and Volpin } \\
\text { (2004); Junni (2011) }\end{array}$ & $\begin{array}{l}\text { McKinsey (2010); Ernst \& Young (2012); } \\
\text { Grant Thornton (2004); AT Kearney } \\
(2007)\end{array}$ \\
\hline Management resources & $\begin{array}{l}\text { Hitt et al. (2009); Marks et al. (2001); } \\
\text { Harvey and Lusch (1995, p. 14) }\end{array}$ & $\begin{array}{l}\text { BCG Consulting (2012); Clifford Chance } \\
\text { (2012); Grant Thornton (2004) }\end{array}$ \\
\hline HR resources & $\begin{array}{l}\text { A. Mukherji, J. Mukherji, Dibrell, and } \\
\text { Francis (2013, p. 41); Fustec and Faroult } \\
\text { (2011, p. 496); McGrady (2005, p. 19); } \\
\text { Lemieux and Banks (2007, p. 1420); } \\
\text { Schuler and Jackson (2001, p. 250) }\end{array}$ & $\begin{array}{l}\text { Deloitte (2009); BCG Consulting (2012); } \\
\text { Mercer Consulting (2008) }\end{array}$ \\
\hline \multicolumn{3}{|l|}{ Financial factors and acquisition premium } \\
\hline $\begin{array}{l}\text { Financial factors (balance sheet and fixed } \\
\text { asset evaluation, debt-ratio, cash-flow } \\
\text { generation, future investment need) } \\
\text { Debt factors (extent of debt, future interest } \\
\text { payments) }\end{array}$ & $\begin{array}{l}\text { Gleich et al. (2010, p. 23); Knecht and } \\
\text { Calenbuhr (2007, p. 423); Epstein (2005, } \\
\text { p. 40); Harvey and Lusch (1995, p. 16); } \\
\text { Marks et al. (2001, p. 84) }\end{array}$ & $\begin{array}{l}\text { BCG Consulting (2012); Kroll Advisory } \\
\text { (2013); Clifford Chance (2012); } \\
\text { McKinsey (2010); Grant Thornton (2004) }\end{array}$ \\
\hline Evaluation and acquisition price premium & $\begin{array}{l}\text { Gomes et al. (2013, p. 19); Malhotra and } \\
\text { Zhu (2013, p. 271); Kim, Haleblian, and } \\
\text { Finkelstein (2011, p. 27); Carbonara and } \\
\text { Rosa (2009, p. 95); Hitt et al. (2009); } \\
\text { King et al. (2004) }\end{array}$ & $\begin{array}{l}\text { BCG Consulting (2012); Clifford Chance } \\
\text { (2012); AT Kearney (2007); McKinsey } \\
\text { (2010); Clifford Chance (2012) }\end{array}$ \\
\hline
\end{tabular}


(Table 1 continued)

\begin{tabular}{|c|c|c|}
\hline Evaluated risk factor & Selected research source & \\
\hline \multicolumn{3}{|l|}{ Macro-factors/business environment } \\
\hline Differences in tax and legal system & $\begin{array}{l}\text { Harvey and Lusch (1995, p. 11); Knecht } \\
\text { and Calenbuhr (2007, p. 423); Kissin and } \\
\text { Herrera (1990, p. 53); Haspeslagh and } \\
\text { Jemison (1991); Very and Schweiger } \\
\text { (2001, p. 15); Firstbrook (2007, p. 53); } \\
\text { Hopkins (1999, p. 233) }\end{array}$ & $\begin{array}{l}\text { Ernst \& Young (2012); Clifford Chance } \\
\text { (2012); AT Kearney (2007); Baker \& } \\
\text { McKenzie (2013); Accenture (2008); } \\
\text { Mercer Consulting (2008); Grant } \\
\text { Thornton (2004) }\end{array}$ \\
\hline Environmental regulations & $\begin{array}{l}\text { Carbonara and Rosa (2009, p. 95); Very } \\
\text { and Schweiger (2001, p. 15); Harvey and } \\
\text { Lusch (1995, p. 12); Hopkins (1999, } \\
\text { p. 233) }\end{array}$ & $\begin{array}{l}\text { Ernst \& Young (2012); Grant Thornton } \\
(2004)\end{array}$ \\
\hline $\begin{array}{l}\text { Corporate governance factors (corruption, } \\
\text { related parties, etc.) }\end{array}$ & $\begin{array}{l}\text { Knecht and Calenbuhr (2007, p. 429); } \\
\text { Rossi and Volpin (2004, p. 298); Bertrand } \\
\text { and Betschinger (2012, p. 417) }\end{array}$ & $\begin{array}{l}\text { AT Kearney (2013); Deloitte } \\
\text { Baker \& McKenzie (2013); } \\
\text { Consulting (2008); Kroll Advisory }\end{array}$ \\
\hline
\end{tabular}

Note. Source: Author's literature review.

\section{The Consistency of Consulting Literature With Academic Results}

Most of the evaluated risk factors mentioned in the practical studies have already been researched in the academic literature. Business consulting studies mainly focus on overcoming the practical obstacles in the acquisition process and show the area where involvement of consulting companies delivers added value. They also consider the operational deal execution as the crucial success criterion identifying the potential impact on operating performance in the post-acquisition phase. In line with academic research, business consulting studies show that the best ingredient of a successful acquisition is an acquirer's strategic focus combined with acquisition that complements their own business capabilities and technological competence. The second most mentioned ingredient of a successful acquisition is the cultural and organizational fit, which takes effects mainly in the post-integration phase. The retention of the key employees of the acquired company is seen as very valuable at both approaches. The third ingredient of a successful acquisition is the evaluation and the acquisition price premium based on evaluated synergy effects, which is mainly based on risk adaptation from due diligence findings. The fourth ingredient comprises intangible factors, i.e., regulatory, political changes, corporate governance, corruption and fraud, etc., which can be subsumed as the "new risks" out of increasing regulatory purpose of corporate governance. Consideration of further intangible aspects is the assessment of economic and political framework of the host country and the probability of changes in that environment which may influence the business model of the acquired entity. As the political institutions tend to be weak in emerging markets, and power often lies in the hands of the elite, the acquirer may face a changeable and unpredictable operating environment. In the research context, those intangible risk factors can be subsumed as legal risks in foreign jurisdiction, as they mainly result out of regulatory cross-border aspects. Furthermore, the business consulting studies selectively warn on reputational issues, integrity risks arising from money laundering, and conflict of interest or business relationships, which are mainly subsumed in corporate governance. However, with the growing importance of these factors, they might receive higher attention in future academic research field in the future. Considering the frequency of the evaluated risk factors, the strategic fit, organizational fit, and cultural fit are the most important areas in the pre-acquisition process. Further risks are in the legal and tax area, mainly implied through differences within geographically different jurisdictions. 


\section{Conclusions, Proposals, and Recommendations}

The literature research shows no comprehensive study which considers the full range of factors to be considered in pre-acquisition evaluation within the due diligence process. Thus, this thesis is the novelty as it considers all of the identified factors and their impact on the acquisition performance. Academicians and business consultants find much to agree: strategic fit, organizational fit, HR factors, and evaluation topics are crucial in the due diligence proceedings. They also have in common that extensive due diligence when executing M\&A transaction, in either developed or emerging markets, is indispensable. At that point, the traditional, in the literature, mostly researched due diligence approach partially falls short, as it concentrates largely on very tangible risks, i.e., as the financial, legal, or operational issues, and only partially on intangible risks, reputational issues, political changes, etc.. A further aspect drawn from the consulting studies is the need for covering necessary pre-acquisition needs of the acquirer in emerging markets, as these transactions differ from those in domestic and/or developed markets. The academic studies show a broader approach and adopt a long-term perspective while business consultants take a more "how to", or more detailed approach. Based on that, academic approach can be enriched when expanding the level of due diligence by a variety of issues experienced in the past-acquisition process. In special situations, limitations are given for performing broad and detailed due diligence. Harvey and Lusch (1995) categorized the issues in as time restrictions, cost constraints, and situational factors. Under time restriction, it is often the case that the effective examination of the target acquisition, beyond the major financial, legal, tax, and future sales projections, does not occur. Finally, situational factors for performing a limited due diligence are most notably with cross-border acquisitions and hostile takeovers because the competitive nature of bidding for a company has required or has not allowed full-scope due diligence.

As the considered surveys show, an acquirer needs to consider using a consistent and scalable process for assessing such typical risks across acquiring in the emerging markets. That means placing the same importance to reputational due diligence as on legal, financial, operational, and other traditional due diligence. The move to the next level of performing due diligence requires more enhancing than replacing traditional due diligence activities. The due diligence scope will be longer but they will be forward-looking and more post-merger-oriented. On the other side, the "new" risk fields are almost all non-quantifiable and the more they have been assessed, the more difficult it is to determine the quantitative impact. The nature of the local environment and its nationality (e.g., government policies or strong unions) may have a bearing on the ability of the acquirers to implement practices during post-merger integration, such as changes in salary and benefits, recruiting, turnover, and labor relations. A stronger legal and institutional environment in the target country leads to increased transaction cost for cross-border deals. This issue coincides with regulatory changes in countries with a strong legal and institutional environment, which may make access to markets for firms from countries with weak legal and institutional environments more difficult. However, each M\&A has its own "personality" and thus, the applicability of the expanded due diligence process may vary from one situation to the next.

The results lead to the suggestion of improving the transfer from the best practice of consultancies to the scientific work due to more openness of the facts from M\&As. An important factor is the input from experienced executives from acquirers and their advisers in M\&As in emerging markets. As it is often difficult to ensure the transfer from the practical to theoretical knowledge and vice versa, an integrated approach is likely to develop with a growing amount of experience in growing frequency of M\&As in the emerging markets and the nature and scope of the due diligence process need to be examined in light of these new trends. This will help to ensure that the M\&As' deal execution intelligence gets a wider scope of the risk assessment methods and finally improve the success rates in cross-border acquisitions. 


\section{References}

Accenture. (2008). Cross-border M\&A: Handle with care. Accenture Outlook 2008. London.

Adolph, G., Gillies, S., \& Krings, J. (2006). Strategic due diligence: A foundation for M\&A success. Strategy + Business, pp. 1-8.

Ahammad, M. F., \& Glaister, K. W. (2013). The pre-acquisition evaluation of target firms and cross border acquisition performance. International Business Review, 22(5), 894-904.

Angwin, D. (2001). Mergers and acquisitions across European borders: National perspectives on preacquisition due diligence and the use of professional advisers. Journal of World Business, 36(1), 32-57.

AT Kearney. (2007). The rise of emerging markets in mergers and acquisitions: Developing countries are gaining strength and influence. London: AT Kearney.

AT Kearney. (2013). M\&A deal evaluation: Challenging metrics myths. London: AT Kearney.

Baker \& McKenzie. (2013). Opportunities across high-growth markets: Trends in cross-border M\&A. London.

Barkema, H. G., \& Schijven, M. (2008). How do firms learn to make acquisitions? A review of past research and an agenda for the future. Journal of Management, 34(3), 594-634.

BCG Consulting. (2012). M\&A: Using uncertainty to your advantage. A survey of European companies' merger and acquisition plans for 2012. London: BCG Consulting.

Belian, M. (2009). Due Diligence Prüfung bei Unternehmenstransaktionen. Hamburg: Verlag Dr. Kovac.

Berens, W., Brauner, H. U., \& Strauch, J. (2011). Due Diligence bei Unternehmensakquisitionen. Verlag: Schäffer-Poeschel.

Bertrand, O., \& Betschinger, M. A. (2012). Performance of domestic and cross-border acquisitions: Empirical evidence from Russian acquirers. Journal of Comparative Economics, 40(3), 413-437.

Carbonara, G., \& Rosa, C. (2009). Factors affecting M\&A success: A starting point for the topic renaissance. The Journal of American Academy of Business, 15(1), 92-99.

Child, J., Faulkner, D., \& Pitkethly, R. (2001). The management of international acquisitions: Realizing their potential value. Oxford: Oxford University Press.

Clifford Chance. (2012). Cross-border M\&A: Perspectives on a changing world. London.

Cullinan, G., Le Roux, J. M., \& Weddigen, R. M. (2004). When to walk away from a deal? Harvard Business Review, 82(4), 96-104.

Deloitte. (2009). Finding value navigating M\&A risks in Central and Eastern Europe. Frankfurt.

Deloitte. (2012). Look before you leap: Navigating risks in emerging markets. Frankfurt.

Epstein, M. J. (2005). The determinants and evaluation of merger success. Business Horizons, 48(1), 37-46.

Ernst \& Young. (2012). M\&A in a two-speed world: Assessing risks and opportunities in rapid-growth markets. Stuttgart.

Feito-Ruiz, I., \& Menéndez-Requejo, S. (2011). Cross-border mergers and acquisitions in different legal environments. International Review of Law and Economics, 31(3), 169-187.

Firstbrook, C. (2007). Transnational mergers and acquisitions: How to beat the odds of disaster. Journal of Business Strategy, 28(1), 53-56.

Fustec, A., \& Faroult, T. (2011). Mergers and acquisitions in the insurance sector: Reducing information asymmetry. Journal of Intellectual Capital, 12(4), 495-504.

Gaughan, P. A. (2011). Mergers, acquisitions, and corporate restructurings (4th ed.). Hoboken, New Jersey, NJ: John Wiley \& Sons, Inc..

GE Capital. (2012). Due diligence: Main steps and success factors. Chicago: General Electric Capital Corporation.

Gleich, R., Kierans, G., \& Hasselbach, T. (2010). Value in due diligence: Contemporary strategies for mergers and acquisitions success. Gower Publishing.

Gole, W. J., \& Hilger, P. J. (2009). Due diligence: An M\&A value creation approach. Hoboken, New Jersey, NJ: John Wiley \& Sons.

Gomes, E., Angwin, D. N., Weber, Y., \& Tarba, S. Y. (2013). Critical success factors through the mergers and acquisitions process: revealing pre- and post-M\&A connections for improved performance. Thunderbird International Business Review, 55(1), 13-35.

Grant Thornton. (2004). Due diligence review: M\&A behind the scenes. Frankfurt.

Harvey, M. G., \& Lusch, R. F. (1995). Expanding the nature and scope of due diligence. Journal of Business Venturing, 10, 5-21.

Haspeslagh, P. C., \& Jemison, D. B. (1991). The challenge of renewal through acquisitions. Planning Review, 19(2), 27-30. 
Hitt, M. A., King, D., Krishnan, H., Makri, M., Schijven, M., Shimizu, K., \& Zhu, H. (2009). Mergers and acquisitions: Overcoming pitfalls, building synergy, and creating value. Business Horizons, 52(6), 523-529.

Hopkins, H. D. (1999). Cross-border mergers and acquisitions: Global and regional perspectives. Journal of International Management, 5(3), 207-239.

Junni, P. (2011). Knowledge transfer in mergers and acquisitions: Fear of exploitation and contamination. Scandinavian Journal of Management, 27(3), 307-321.

Kim, J. Y., Haleblian, J., \& Finkelstein, S. (2011). When firms are desperate to grow via acquisition: The effect of growth patterns and acquisition experience on acquisition premiums. Administrative Science Quarterly, 56(1), 26-60.

King, D. R., Dalton, D. R., Daily, C. M., \& Covin, J. G. (2004). Meta-analyses of post-acquisition performance: Indications of unidentified moderators. Strategic Management Journal, 25(2), 187-200.

Kissin, W. D., \& Herrera, J. (1990). International mergers and acquisitions. The Journal of Business Strategy, 11(4), 51-54.

Knecht, F., \& Calenbuhr, V. (2007). Using capital transaction due diligence to demonstrate CSR assessment in practice. Corporate Governance: The International Journal of Business in Society, 7(4), 423-433.

Kroll Advisory. (2013). Private equity into high-risk markets: The need for a new due diligence approach.

Lee, K., \& Pennings, J. M. (1996). Mergers and acquisitions: Strategic-organizational fit and outcomes. Retrieved from http://www-management.wharton.upenn.edu/pennings/documents/Mergers_Acquisitions.pdf

Lemieux, O. P., \& Banks, J. C. (2007). High tech M\&A - Strategic valuation. Management Decision, 45(9), 1412-1425.

Malhotra, S., \& Zhu, P. C. (2013). Paying for cross-border acquisitions: The impact of prior acquirers' decisions. Journal of World Business, 48(2), 271-281.

March, J. G. (1991). Exploration and exploitation in organizational learning. Organization Science, 2(1), 71-87.

Marks, M., Mirvis, P. H., \& Brajkovich, L. F. (2001). Making mergers and acquisitions work: Strategic and psychological preparation. Academy of Management Executive, 15(2), 80-94.

McDonald, J., Coulthard, M., \& De Lange, P. (2005). The importance of strategic planning and due diligence in mergers and acquisitions: An Australian perspective. Working Paper 49/05, Department of Management.

McGrady, S. (2005). Extending due diligence to improve mergers and acquisitions. Bank Accounting and Finance, 18(4), 17-23.

McKinsey. (2010). A new generation of M\&A: A McKinsey perspective on the opportunities and challenges. London: McKinsey \& Company.

Mercer Consulting. (2008). M\&A beyond borders: Opportunities and risk. Marsh, Mercer, Kroll in cooperation with the Economist Intelligence Unit.

Morrison, N. J., Kinley, G., \& Ficery, K. L. (2008). Merger deal breakers: When operational due diligence exposes risk. Journal of Business Strategy, 29(3), 23-28.

Mukherji, A., Mukherji, J., Dibrell, C., \& Francis, J. D. (2013). Overbidding in cross-border acquisitions: Misperceptions in assessing and valuing knowledge. Journal of World Business, 48(1), 39-46.

Pau, P. (2009). Getting a good deal: M\&A best practices. Horizons: New Perspectives on M\&A Success, pp. 65-81.

Perry, J. S., \& Herd, T. J. (2004). Mergers and acquisitions: Reducing M\&A risk through improved due diligence. Strategy and Leadership, 32(2), 12-19.

Roland Berger. (2011). M\&A activities in CEE/SEE in 2010: Waiting for the next growth phase. Munich.

Rossi, S., \& Volpin, P. F. (2004). Cross-country determinants of mergers and acquisitions. Journal of Financial Economics, 74(2), 277-304.

Schuler, R., \& Jackson, S. (2001). HR issues and activities in mergers and acquisitions. European Management Journal, 19(3), 239-253.

Schweiger, D. M., \& Very, P. (2003). Creating value through mergers and acquisition integration. Advances in Mergers and Acquisitions, 2, 1-26.

Shimizu, K., Hitt, M. A., Vaidyanath, D., \& Pisano, V. (2004). Theoretical foundations of cross-border mergers and acquisitions: A review of current research and recommendations for the future. Journal of International Management, 10(3), 307-353.

Very, P., \& Schweiger, D. M. (2001). The acquisition process as a learning process: Evidence from a study of critical problems and solutions in domestic and cross-border deals. Journal of World Business, 36(1), 11-31.

Wirtz, B. W. (2012). Mergers \& acquisitions management: Strategie und Organisation von Unternehmenszusammenschlüssen (2nd ed.). Wiesbaden: Gabler Verlag.

Zademach, H. M., \& Rodríguez-Pose, A. (2009). Cross-border M\&As and the changing economic geography of Europe. European Planning Studies, 17(5), 765-789. 